\title{
Cytogenetic Effects of Fungicide Afugan on the Meristematic Cells of Allium cepa L.
}

\author{
Deniz Yüzbaşıŏlu* \\ Gazi Üniversitesi, Fen-Edebiyat Fakültesi, Biyoloji Bölümü, Teknikokullar, Ankara, Turkey
}

Received March 17, 2003; accepted July 11, 2003

\begin{abstract}
Summary In this study, the cytogenetic effects of afugan were investigated in root tip cells of Allium cepa $\mathrm{L} . \mathrm{EC}_{50}$ value of this fungicide was determined as $40 \mathrm{ppm}$ using root growth inhibition test and then the roots of Allium cepa were treated with 10,20, 40 and $60 \mathrm{ppm}$ concentrations for 12, 24 and $48 \mathrm{~h}$. Mitotic index, mitotic phase frequencies and mitotic abnormalities were determined for each concentration and treatment period. The most common types of abnormality are stickiness, cmitosis, bridges, lagging chromosomes, fragments, multipolarity and micronucleated cells.
\end{abstract}

Key words Afugan, fungicide, mitosis, mitotic abnormalities, Allium cepa.

A number of pesticides are used extensively in the modern agricultural practise. Increased utilization of pesticides for crop protection in modern agriculture has raised the question whether these chemicals induce any detectable cytological damage to the cells. Several bioassays have been proposed for the monitoring of mutagenicity of environmental chemicals (Epstein and Legator 1971). Consequently, many short term studies based on in vitro and in vivo test were successfully carried out for the detection and monitoring of a wide variety of environmental chemicals with mutagenic and carcinogenic potential (Ashby et al. 1988).

Previous studies have shown that plant chromosomes are excellent materials, as they are large and sensitive to changes in the environment (Kihlman 1975, Grant 1978). Since Levan (1938) introduced the first Allium test, various chemicals have been tested for their cytogenetic activities using this test (Hidalgo et al. 1989, Ahmad and Yasmin 1992, Topaktaş and Rencüzoğulları 1996, Sudhakar et al. 2001, Yüzbaşığlu et al. 2003). Fungicides are among the least investigated pesticides for their genotoxic effects. Cytogenetic activities of some fungicides were investigated in different plants (Cortes et al. 1982, Badr 1988, Vera Lopez et al. 1990, Shahin and El-Amoodi 1991, Ahmad and Yasmin 1992, Amer et al. 1999).

In the present study, the cytogenetic effects of fungicide afugan in the root tips of Allium cepa L. were studied and the results are reported.

\section{Material and methods}

Afugan used in the present investigation is a systemic fungicide and belongs to pyrimidine group. Its selected trade names are pyrazophos. Its chemical composition is ethyl 2-diethoxyphosphinothioyloxy-5-methylpyrazolo [1,5-a]=pyrimidine-6-carboxylate; 0,0-diethyl 0-6-ethoxycarbonyl-5-methylpyrazola $=[1,5$-a]pyrimidin-2-yl phosphorothioate, CAS rejistry number: 13457-186. Chemical formula is $\mathrm{C}_{14} \mathrm{H}_{20} \mathrm{~N}_{3} \mathrm{O}_{5}$ PS. Molecular weight is 373.4. The structural formula is as the following:

\footnotetext{
* Corresponding author, e-mail: deniz@gazi.edu.tr
} 


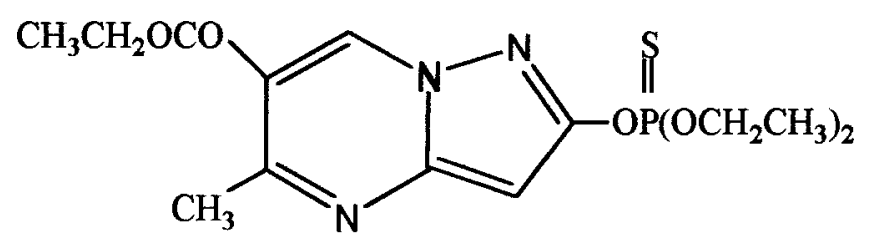

It is used to control of Erysiphe, Helminthosporium and Rhynchosporium in cereals, Podosphaera in pome fruit, Erysiphe and Sphaerotheca in cucurbits, Erysiphe in tomatoes, Oidium and Podosphaera in stone fruit, and Uncinula in grapes.

Equal sized bulbs are chosen from a population of the common onion Allium cepa L. $(2 n=16)$. The growth inhibition test was carried out prior to the genotoxicity test when working with the Allium assay. Onion bulbs were placed ower the test tubes filled with the test concentration of afugan $(10,20,30,40,50,60,70,80,90,100,150,250,300,500 \mathrm{ppm})$. A set of 5 bulbs was also run in distilled water. The root lengths from the control and experimental sets were measured (lenghts of 10 roots from each bulb) on the 5th day as described earlier (Fiskesjö 1985). Then this measurement was used to calculate the $\mathrm{EC}_{50}$ value, which is the concentration where root growth is reduced by $50 \%$ compared with control. Thus, $\mathrm{EC}_{50}$ value of afugan was determined as $40 \mathrm{ppm}$ and then the roots of bulbs were treated with $60 \mathrm{ppm}\left(\mathrm{EC}_{50 \times 3 / 2}\right), 40 \mathrm{ppm}\left(\mathrm{EC}_{50}\right), 20 \mathrm{ppm}\left(\mathrm{EC}_{50 / 2}\right), 10 \mathrm{ppm}\left(\mathrm{EC}_{50 / 4}\right)$ concentrations.

A. cepa bulbs were germinated in distilled water at room temperature $\left(20 \pm 2^{\circ} \mathrm{C}\right)$. When the roots reached $1.5-2 \mathrm{~cm}$, they were treated with each concentration of afugan for 12, 24 and $48 \mathrm{~h}$. Twelve onions were setup at each concentration. The same amount of onions were used as control in all applications. At the end of the treatments, the roots were excised from the bulb, washed with water and fixed in 3:1 alcohol : acetic acid for $24 \mathrm{~h}$ and stored in $70 \%$ alcohol in refrigerator until use. The cytological preparations followed Feulgen schedule (Darlington and La Cour 1976) from 10 different onions. Mitotic index $(\mathrm{MI}=$ the number of dividing cells/total number of cells $\times 100)$, the frequency of mitotic phases and the number and type of abnormalities were found by observing 10000 cells. On each slide prepared from different onions, 1000 cells were screened and with 10 onions this reached to 10000 cells for each concentration and duration of time. The data obtained for the mitotic index was statistically analysed using $z$ test and, for the frequency of mitotic phases and abnormalities were analysed using $\chi^{2}$ test.

\section{Results}

Afugan induced evidently dose-dependent root growth inhibition and $\mathrm{EC}_{50}$ value registered as $40 \mathrm{ppm}$. MI was calculated in the presence of 0 (control), 10, 20, 40 and $60 \mathrm{ppm}$ concentrations of afugan. $60 \mathrm{ppm}$ concentrations of this fungicide was toxic in $48 \mathrm{~h}$ treatment and no dividing cells was observed. Afugan decreased the rate of MI significantly in all other concentrations and treatment times as compared to their controls (Table 1).

Afugan has significant effect on the percentage of the mitotic stages at $60 \mathrm{ppm}$ concentration (Table 1). This concentration has significantly decreased the percentage of prophase and telophase at $24 \mathrm{~h}$ and increased the percentage of metaphase at 12 and $24 \mathrm{~h} .60 \mathrm{ppm}$ concentration was toxic at $48 \mathrm{~h}$ treatment.

Afugan caused the induction of a significant percentage of abnormal mitosis in the root tips of Allium cepa in comparison to the control (Table 2). Six types of abnormalities recorded were stickiness, C-mitosis, bridge, lagging chromosomes, fragments and multipolarity (Fig. 1). Stickiness was the predominate abnormality with the frequency of $68.68 \%$. The maximum rate of stickiness was observed in the group treated at $60 \mathrm{ppm}$ for $24 \mathrm{~h}$. Following, C-mitosis was observed as $17.43 \%$. Bridges and laggards were detected as $6.50 \%$ and $5.59 \%$, respectively. In addition these, fragments 
Table 1. The percentage of mitotic index and mitotic phase frequencies in the root tips of $A$. cepa exposed to the afugan

\begin{tabular}{|c|c|c|c|c|c|}
\hline \multirow{2}{*}{ Conc. (ppm) } & \multirow{2}{*}{$\mathrm{MI} \pm \mathrm{S} . \mathrm{E}$. } & \multicolumn{4}{|c|}{ Mitotic phases (\%) } \\
\hline & & Prophase & Metaphase & Anaphase & Telophase \\
\hline \multicolumn{6}{|l|}{$12 \mathrm{~h}$} \\
\hline Control & $7.13 \pm 0.26$ & 36.19 & 32.96 & 17.39 & 13.46 \\
\hline 10 & $4.81 \pm 0.21^{\mathrm{a}}$ & 45.11 & 24.74 & 16.22 & 13.93 \\
\hline 20 & $3.99 \pm 0.19^{\mathrm{a}}$ & 48.37 & 25.06 & 12.78 & 13.79 \\
\hline 40 & $3.99 \pm 0.19^{\mathrm{a}}$ & 41.10 & 34.84 & 13.03 & 11.03 \\
\hline 60 & $1.98 \pm 0.14^{\mathrm{a}}$ & 22.22 & $59.09 *$ & 11.11 & 7.58 \\
\hline \multicolumn{6}{|l|}{$24 \mathrm{~h}$} \\
\hline Control & $6.13 \pm 0.24$ & 31.16 & 35.72 & 13.87 & 19.25 \\
\hline 10 & $4.29 \pm 0.20^{\mathrm{a}}$ & 42.89 & 29.14 & 14.22 & 13.75 \\
\hline 20 & $3.21 \pm 0.18^{\mathrm{a}}$ & 41.43 & 25.86 & 16.20 & 16.51 \\
\hline 40 & $2.71 \pm 0.16^{\mathrm{a}}$ & 41.70 & 39.85 & 6.27 & 12.18 \\
\hline 60 & $2.04 \pm 0.14^{\mathrm{a}}$ & $15.20^{*}$ & $77.45^{* *}$ & 5.39 & $1.96^{* *}$ \\
\hline \multicolumn{6}{|l|}{$48 \mathrm{~h}$} \\
\hline Control & $6.31 \pm 0.24$ & 34.23 & 30.74 & 17.12 & 17.91 \\
\hline 10 & $4.25 \pm 0.20^{\mathrm{a}}$ & 47.29 & 25.18 & 13.41 & 14.12 \\
\hline 20 & $3.45 \pm 0.18^{\mathrm{a}}$ & 51.30 & 28.41 & 8.99 & 11.30 \\
\hline 40 & $2.73 \pm 0.16^{\mathrm{a}}$ & 33.70 & 44.69 & 9.52 & 12.09 \\
\hline 60 & Toxic & Toxic & Toxic & Toxic & Toxic \\
\hline
\end{tabular}

${ }^{a}$ Significant from the control $p<0.001$ ( $z$ test $) .{ }^{*}$ Significant from the control $p<0.05$ ( $\chi^{2}$ test $) . * *$ Significant from the control $p<0.001\left(\chi^{2}\right.$ test $)$.

Table 2. Type and percentage of mitotic abnormalities in the root tips of $A$. cepa exposed to the afugan

\begin{tabular}{|c|c|c|c|c|c|c|c|c|c|}
\hline \multirow{2}{*}{$\begin{array}{l}\text { Conc. } \\
\text { (ppm) }\end{array}$} & \multirow{2}{*}{$\begin{array}{l}\text { No. of } \\
\text { dividing } \\
\text { cells }\end{array}$} & \multicolumn{6}{|c|}{ Abnormalities (\%) } & \multirow{2}{*}{$\begin{array}{c}\text { Total } \\
\text { abnormalities } \\
(\%)\end{array}$} & \multirow{2}{*}{$\begin{array}{c}\text { Abnormal } \\
\text { interphase } \\
\text { cells }(\%)\end{array}$} \\
\hline & & Stickiness & $\mathrm{C}$-mitosis & Bridges & Laggards & Fragments & Multipolarity & & \\
\hline \multicolumn{10}{|l|}{$12 \mathrm{~h}$} \\
\hline Control & 713 & - & - & - & - & - & - & 0.00 & 0.00 \\
\hline 10 & 481 & 2.08 & 6.23 & - & 3.12 & 0.83 & 0.83 & $13.09^{* *}$ & 0.07 \\
\hline 20 & 399 & 11.03 & 2.76 & 0.25 & 0.75 & 1.75 & - & $16.54 * *$ & 0.19 \\
\hline 40 & 399 & 24.31 & 11.28 & 3.01 & 5.26 & - & - & $43.86^{* *}$ & 0.20 \\
\hline 60 & 198 & 44.95 & 20.20 & 6.06 & 4.04 & - & - & $75.25^{* *}$ & 0.16 \\
\hline \multicolumn{10}{|l|}{$24 \mathrm{~h}$} \\
\hline Control & 613 & - & - & - & - & - & - & 0.00 & 0.00 \\
\hline 10 & 429 & 7.92 & 7.23 & 0.23 & 0.47 & - & 0.23 & $16.08^{* *}$ & 0.06 \\
\hline 20 & 321 & 10.90 & 4.05 & 0.62 & 1.87 & 0.93 & 0.31 & $18.68 * *$ & 0.24 \\
\hline 40 & 271 & 33.95 & 4.43 & 6.27 & 3.32 & - & 0.37 & $48.34^{* *}$ & 0.40 \\
\hline 60 & 204 & 82.35 & 0.49 & 1.96 & - & - & - & $84.80^{* *}$ & 0.42 \\
\hline \multicolumn{10}{|l|}{$48 \mathrm{~h}$} \\
\hline Control & 631 & 0.32 & 0.32 & 0.16 & - & - & - & 0.80 & 0.00 \\
\hline 10 & 425 & 10.35 & 2.35 & 0.71 & - & 0.71 & 0.23 & $14.35^{* *}$ & 0.13 \\
\hline 20 & 345 & 16.23 & 6.67 & 0.87 & 1.16 & 0.29 & 0.29 & $25.51 * *$ & 0.21 \\
\hline 40 & 273 & 41.76 & 6.59 & 6.96 & 3.30 & - & 0.73 & $59.34 * *$ & 0.61 \\
\hline 60 & Toxic & Toxic & Toxic & Toxic & Toxic & Toxic & Toxic & Toxic & Toxic \\
\hline
\end{tabular}

** Significant from the control $p<0.001\left(\chi^{2}\right.$ test $)$.

(1.08\%) and multipolarity $(0.72 \%)$ were also observed (Fig. 1$)$. $60 \mathrm{ppm}$ concentration was toxic $48 \mathrm{~h}$ treatment. Afugan increased the percentage of abnormal cells compared to the control in all concentrations and duration of treatments. Afugan has also induced micronucleated cells at inter- 


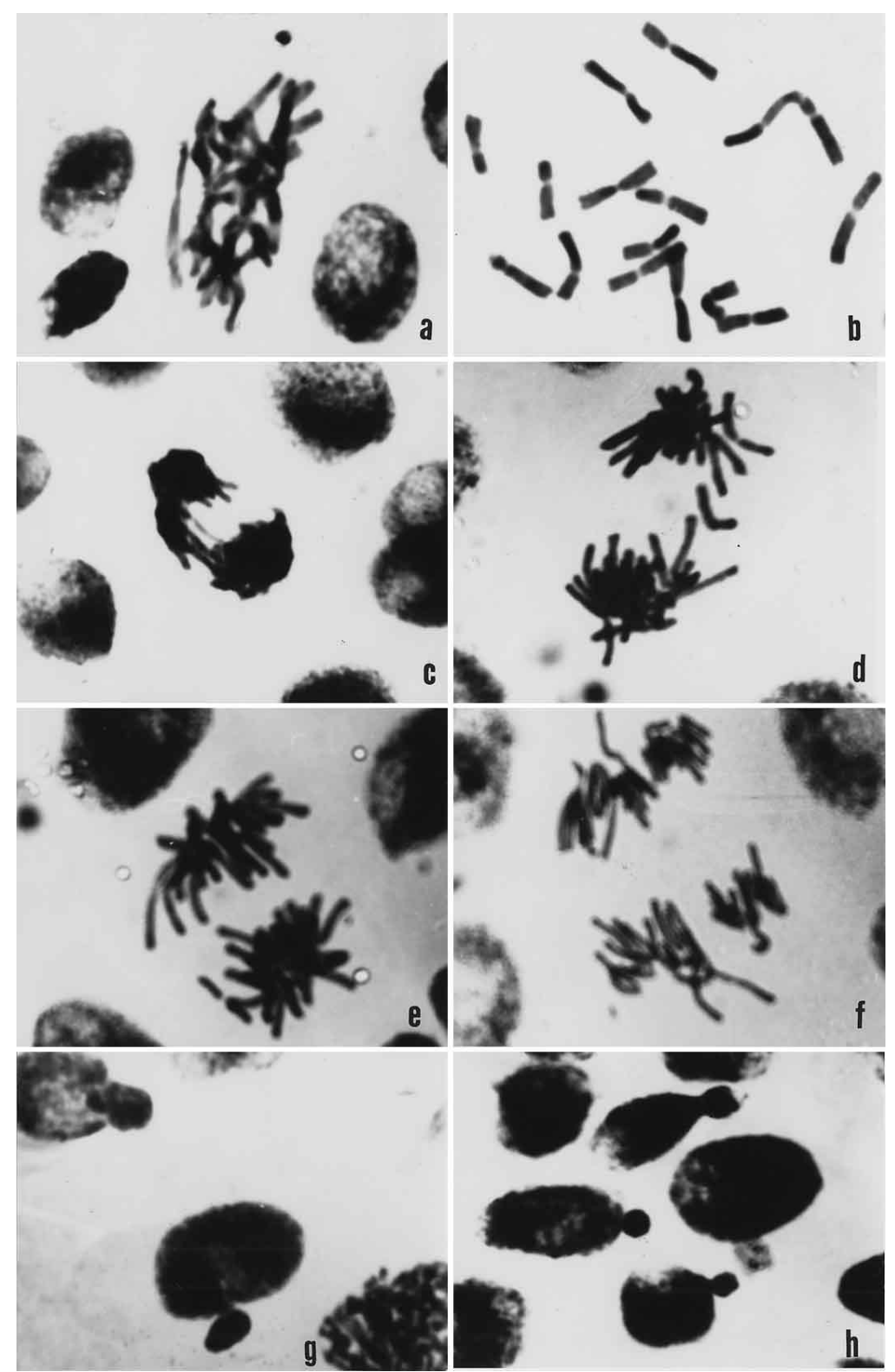

Fig. 1. Different types of aberrations induced by the afugan fungicide in Allium cepa root tips. a) Stickiness. b) C-mitosis. c) Bridge. d) Lagging chromosome. e) Fragment. f) Multipolarity. g, h) Micronucleated cells.

phase. However, the rate of micronuclei containing cells were not significant when compared to the controls (Table 2).

\section{Discussion}

Allium test has been used widely for the monitoring of genetic effects of different chemicals (Fiskesjö 1985, Badr 1988, Topaktaş and Rencüzoğulları 1996, Sudhakar et al. 2001, Yüzbaşığlu et al. 2003). The positive results in the Allium test should be considered as a warning. It also indi- 
cate that the tested chemical may be a risk to human health and to the environment (Fiskesjö 1985).

In the present study afugan significantly decreased the MI at all concentrations and treatment periods as compared to their controls. As the concentration increased MI value was gradually decreased. $60 \mathrm{ppm}$ concentration of afugan was toxic in $48 \mathrm{~h}$ treatment and no dividing cells was observed. Decreasing in mitotic index have been reported to other pesticides (Cortes et al. 1982, Somashekar et al. 1984, Badr 1988, Ahmad and Yasmin 1992). Decreasing of the MI could be due to blocking of $\mathrm{G}_{1}$ suppressing DNA synthesis (Schneiderman et al. 1971) or a blocking of $\mathrm{G}_{2}$ preventing the cell from entering mitosis (Van't Hof 1968). The lowering of MI might have been achieved by the inhibition of DNA synthesis at S-phase (Sudhakar et al. 2001). Hidalgo et al. (1989) reported that the inhibition of certain cell cyle specific proteins remains as a possible pesticide target site. Thus inhibition of the enzyme DNA polymerase, which is necessary for the synthesis of DNA as well as other enzymes more directly involved with spindle production, assembly or orientation, could explain the reported antimitotic effect.

The treatment conducted with afugan showed that this chemical effects the percentage of the different mitotic stages at $60 \mathrm{ppm}$ concentration, where the percentage of prophase and telophase significantly decreased at $24 \mathrm{~h}$, and the percentage of metaphase increased at 12 and $24 \mathrm{~h}$. Decreasing in prophase may attributed to the inhibition of DNA synthesis at S-phase at highest concentrations. Increasing of metaphase can result from blocking of spindle formation by the fungicide.

Similar action on the mitotic stages has been observed by the treatment of fungicides tridemorp (Cortes et al. 1982) and thiram (Vera Lopez et al. 1990). Topaktaş and Rencüzoğulları (1996) reported that marshal significantly decreased the ratio of cells in the prophase stages of mitotic division depending on the treatment times. The ratio of the cells in the metaphase stage significantly increased while the ratio of the cells in the anaphase and telophase stages significantly decreased when compared with the control group. The fungicide dithane caused a reduction in the proportion of prophase (Badr 1988).

The fungicide afugan induced 6 types of mitotic abnormalities in different stages. These abnormalities were stickiness, C-mitosis, bridge, lagging chromosomes, fragment and multipolarity. The percentage of total abnormalities increased significantly with increasing of concentration in each treatment period when compared to their control groups. In addition to the mitotic abnormalities, cells containing micronucleus were also observed at interphase in all treatments. However, the percentage of micronuclei were not significant from the control. The result are in aggrement with those obtained after treating the A. cepa root tips with different pesticides, such as parathion and trimiltox (Ahmad and Yasmin 1992), marshal (Topaktaş and Rencüzoğulları 1996), racer (Yüzbaşığlu et al. 2003), cypermethrin and fenvalerate (Chauhan et al. 1999). Dithane and denmart fungicides exerted c-mitosis, chromosomal stickiness, bridges and breaks. In addition, most treatments of denmart resulted in lagging chromosomes and formation of binucleated and micronucleated cells (Badr 1988).

Stickiness was a major type of abnormality produced by afugan. This abnormality is considered to be a physiological effect exerted by pesticides (Grant 1982). Mc Gill et al. (1974) reported that stickiness has been shown to be the result of entanglement of interchromosomal chromatin fibres and this leads to subchromatid connections between chromosomes. Sticky chromosomes indicated that the chemical highly toxic, usually not reversible effect and probably leading to cell death (Fiskesjö 1985). Several fungicides have been reported to induce stickiness (Somashekar et al. 1984, Badr 1988, Ahmad and Yasmin 1992).

The formation of C-mitosis, lagging chromosome(s) and multipolarity may be due to the disturbance in the spindle formation which affected the pesticide (Badr et al. 1985). C-mitosis indicated that, the chemical inhibited spindle formation similar to the effect of colchicine (Badr 1988), and induction of C-mitosis commonly associated with spindle poisons, indicating turbogenic effect (Shahin and El-Amoodi 1991). Several investigations were able to induce C-mitosis in plant cells 
using different fungicides (Somashekar et al. 1984, Badr 1988, Shahin and El-Amoodi 1991).

The chromosomal bridge formation can be due to the general stickiness of the chromosomes at metaphase or because of breakage and reunion of chromosomes indicating clastogenic effect of the chemical used (Tomkins and Grant 1972, Badr 1988). Bridges were also observed in the mitosis of A. cepa after treatment with the fungicide dithane and denmart (Badr 1988) and topsin (Somashekar et al. 1984). In the present study, fragments were also observed in some treatments. Fragments and bridges exerted by the chemical lead to structural changes in chromosomes. Fragmentation of chromosomes might be resulted from the sticky chromosomes. Ahmad and Yasmin (1992) reported that micronuclei may originate from lagging chromosomes or acentric fragments which were observed in mitotic stage. The mitotic abnormalities such as bridges, fragment and micronucleus resulted from a clastogenic action on chromosomal DNA (Grant 1978). In this respect, the clastogenic type aberrations are considered as reliable indicators of mutational change and are used as reliable evidence for screening the mutational activity (Kihlman 1975). As a result, afugan has mitodepressive, clastogenic and turbogenic effects in $A$. cepa and should be regarded as a potential mutagen for non-target organisms.

\section{Acknowledgements}

The author thank to the Gazi University Research Found for financial support under grant no. 05/2002-63. The author also thank to Prof. Dr. Fatma Ünal for her helpful comments on the manuscript.

\section{References}

Ahmad, S. and Yasmin, R. 1992. Effects of methyl paration and tri-miltox on the mitosis of Allium cepa. Cytologia, 57: $155-160$.

Amer, S. M., Mohamed, F. I. and Ashry, Z. M. 1999. Cytogenetic effects of the fungicide benomyl on Vicia faba and Pisum sativum. Bulletin of the National Research Centre 24: 481-494.

Ashby, J., DE Serres, F. J., Shelby, M. D., Margolın, B. H., Ishıdate Jr., M. and Beckıng, G. C. (eds.). 1988. Evaluation of Short-term Test for Carcinogens, Report on the International Programme on Chemical Safety's Collaborative Study on in vivo Assays. I, II. Cambridge Univ. Press, Cambridge.

Badr, A. 1988. Cytogenetic activities of some fungicides. Cytologia 53: 635-640.

- Hamoud, M. A. and Haroun, S. A. 1985. Effect of the herbicide gespax on mitosis, mitotic chromosomes and nucleic acids in Vicia faba L. root meristems. Proc. Saudi. Biol. Soc. 8 (Al Hassa Symp.): 359-370.

Chauhan, L. K. S., Saxena, P. N. and Gupta, S. K. 1999. Cytogenetic effecsts of Cypermethrin and Fenvalerate on the root meristems cells of Allium cepa. Environm. Exper. Bot. 42: 181-189.

Cortes, F., Escalza, P., Moreno, J. and Lopez-Campos, J. L. 1982. Effects of the fungicide tridemorph on mitosis in Allium cepa. Cytobios 34: 181-190.

Darlington, C. D. and La Cour, L. E. 1976. The Handling of Chromosomes. Allen and Unwin, London 201.

Epstein, S. S. and Legator, M. S. 1971. The Mutagenicity of Pesticides-Concepts and Evaluation. The MIT Press. Cambridge, England.

Fiskesjö, G. 1985. The Allium test as a standard in environmental monitoring. Hereditas 102: 99-112.

Grant, W. F. 1978. Chromosomal aberrations in plants as a monitoring system. Environ. Helth. Persp 27: $37-43$.

- 1982. Chromosome aberration assay in Allium. A report of the U.S. Environmental Protection Agency Gene-Tox Programme. Mutat. Res. 99: 273-291.

Hidalgo, A., Gonzales-Reyes, J. A., Navas, P. and Garcia-Herdugo, G. 1989. Abnormal mitosis and growth inhibition in Allium cepa roots induced by propham and chlorpropham. Cytobios. 57: 7-14.

Kihlman, B. A. 1975. Root tips of Vicia faba for the study of the induction of chromosome aberrations. Mutat. Res. 31: 401-412.

Levan, A. 1938. The effect of colchicine on root mitosis in Allium. Hereditas 24: 471-486.

Ma, T. H. and Grant, W. F. 1982. The tradescantias-adventurous plants. Herbarist 48: 36-44.

Mc-Gill, M., Pathak, S. and Hsu, T. C. 1974. Effects of ethidium bromide on mitosis and chromosomes: A possible material basis for chromosomes stickiness. Chromosoma 47: 157-167.

Schneiderman, M. H., Dewey, W. C. and Highfield, D. P. 1971. Inhibition of DNA synthesis in synchronized Chinese ham- 
ster cell treated in $\mathrm{G}_{1}$ with cycloheximide. Exp. Cell Res. 67: 147-155.

Shahin, S. A. and El-Amoodi, K. H. H. 1991. Induction of numerical chromosomal aberrations during DNA synthesis using the fungicides nimrod and rubigan-4 in root tips of Vicia faba L. Mutat. Res., 261: 169-176.

Somashekar, R. K., Gowda, M. T. G. and Venkatasubbaiah, P. 1984. Cytological effects of fungicide topsin in Allium cepa. Cytologia 49: 171-175.

Sudhakar, R., Ninge Gowda, K. N. and Venu, G. 2001. Mitotic abnormalities induced by silk dyeing industry effluents in the cell of Allium cepa. Cytologia 66: 235-239.

Tomkins, D. J. and Grant, W. F. 1972. Comparative cytological effects of pesticides menazon, metrobromuron and tetrachloro isophthalo nitrile in Hordeum and Tradescantia. Can. J. Genet. Cytol. 14: 245-256.

Topaktaş, M. and Rencüzoğulları, E. 1996. Genotoxic effects of marshal in Allium cepa L. Tr. J. Botany 20: $481-487$.

Van't Hof, J. 1968. The action of IAA and kinetin on the mitotic cycle of proliferative and stationary phase excised root meristem. Exp. Cell Res. 51: 167-176.

Vera Lopez, P., Ruiz Rejon, C., Lozano, R. and Ruiz Rejon, M. 1990. Effects of thiram on the mitotic division rhythm in roots of Allium sativum L. Cytobios 62: 135-139.

Yüzbaşığlu, D., Ünal, F., Sancak, C. and Kasap, R. 2003. Cytological effects of herbicide racer "fluorochloridone" on Allium cepa. Caryologia 56: 97-105. 